Article

\title{
For Whom the Bell Tolls: Practitioners' Views on Bell-Ringing Practice in Contemporary Society in New South Wales (Australia)
}

\author{
Murray Parker ${ }^{1}[$ and Dirk H.R. Spennemann $2, *(\mathbb{C}$ \\ 1 School of Environmental Sciences, Charles Sturt University, P.O. Box 789, Albury, NSW 2640, Australia; \\ muparker@csu.edu.au \\ 2 Institute for Land, Water and Society, Charles Sturt University, P.O. Box 789, Albury, NSW 2640, Australia \\ * Correspondence: dspennemann@csu.edu.au
}

Received: 10 July 2020; Accepted: 13 August 2020; Published: 17 August 2020

\begin{abstract}
For centuries, religious buildings have been using bells to call the faithful to prayer. Bell-ringing activity on church premises does not serve a purely religious function, however, as people in the community may perceive this activity secularly, attributing their own meanings and significances towards these sounds. If bell ringing (or the actual sound) were found to have great significance to a specific community, denomination, or a regionality bracket, this may have future implications in any management of these resources. There is a need to hear the voices of the actual practitioners and their perceptions regarding what they, their congregations, and their host communities feel. This paper represents the first large-scale assessment of the views of practitioners of five major Christian denominations with regards to bell-ringing practice and its role in contemporary society.
\end{abstract}

Keywords: cultural heritage; soundscapes; clergy and liturgy; church bells; noise pollution

\section{Introduction}

As a social species living in villages, towns, and cities, humans have created soundscapes that may be ancillary, i.e., emanate from activities conducted by people (e.g., factory sounds, sounds emerging from traffic), or intentional, i.e., emanate from sound-making devices designed to alert the public to dangers (e.g., car horns or loudspeaker announcements at subway stations), or to notify the public of impending events (Parker and Spennemann n.d.b). Examples of the latter are bells rung in a church tower or the Azan broadcast from a minaret, both calling the faithful to attend religious services. These soundscapes are not static but undergo changes concurrent with technological changes in the patterns of the underlying human activity as well as societal changes. Depending on how these soundscapes are perceived, they are regarded as negative ('noise') and thus regulated in terms of their location, recurrence, and volume by means of noise pollution ordinances, or they are perceived as positive, in which case they may be deemed worth keeping/preserving and may be conceptualised as 'heritage' (Parker and Spennemann n.d.c).

The concept of a soundscape was popularised by Schafer in 1977 and has since been developed into an interactive multi-sensory contextual idea, which represents a shift from noise restrictions to an acknowledgement and recognition of a multiplicity of sounds and soundscapes (Botteldooren et al. 2013; Cain et al. 2013; Kang et al. 2016). The acoustic environment can be seen as a resource (Dumyahn and Pijanowski 2011a; Brown 2011), and its meaning and pleasantness is determined by our personal situation, our prior experience, cultural background, the perceived dynamic, and the contextual attributes of the sounds themselves (Kitapci and Galbrun 2015; Lam et al. 2010; Bruce and Davies 2014). Furthermore, demographics invoke different emotional responses to these 
sounds (Cain et al. 2013), and soundscapes can be deemed to have social value to particular communities and provide a quotidian connection to our environment (Dumyahn and Pijanowski 2011b).

Soundscapes comprising particular sounds have been shown to impart meaning into, and to influence beliefs of people's lives in certain societies, such the value placed on the 'Isobue' or sea whistle of divers in east Japan, providing an invisible tangible sense of place for the community (Kato 2009); the deep connection with community of the symbolic sounds of textile factories in Fujiyoshida, Japan (Minoura 2013); the secular and sacred symbolism of the ringing of village church bells in nineteenth-century France (Corbin 1998); and the multifaceted relationships created by both urban and rural bells into European society (Feld and Brenneis 2004). Sounds and soundscapes can be both the symbolism and the connective force, linking an individual, a culture, or a community with belief and being, as well as evoking emotive responses by society concerning human existence.

For centuries, religious buildings have used external bells to call the faithful to prayer (Gatty 1848). The oldest bell still in use is the Okikicho bell (cast in 698) located at the Myōshin-ji Buddhist temple complex, Kyoto (Japan) (Rossing 2000, p. 179). Among the oldest Christian church bells on record is a peal installed in St Peter's in Monks Eleigh (Suffolk, UK), which contains a 14-hundredweight (cwt) bell cast in 1347 and a 9-cwt bell cast in 1470, as well as a peal installed in St Lawrence in Ipswich (Suffolk, UK), with five bells between $4 \mathrm{cwt}$ and $13 \mathrm{cwt}$ dating to 1440, 1449, and 1490 (Baldwin et al. 2018; Raven 1890).

While church bells were ubiquitous until the mid-twentieth century and could be found in almost all Christian churches if the congregational finances allowed it, societal change in the post-World War II era has seen a decline in bell use and bell installation in recently consecrated churches. Judging by media reports, there is an increasing discontent among residents living near religious premises, with noise complaints about bell ringing on record, inter alia, from places as diverse as England (Hargraves 2018; Carney 2014; Gerder 2020; Vickery 2020), France (Connexion 2019), Malta (Borg 2007), Slovenia (Plahuta 2013), South Africa (Pimentel 2019), and Switzerland (Bachmann 2018), as well as various states of the USA, e.g., California (Park and Mac 2015), New York (Kaysen 2015), and Vermont (Rathke 2015). Some of these complaints led to the silencing of bells via local ordinances or court decisions, such as in England (BBC 2017a, 2017b; Minchin 2010; Bunyan 2009), Ireland (Kelly 2013), Italy (Hooper 2008; Scammell 2015), Poland (Union of Catholic Asians 2012), and Switzerland (Local 2018) as well as in various states of the USA, e.g., Arizona (Catholic News Agency 2009) and Pennsylvania (Wood 2010). In the Australian setting this has occurred in Brisbane (Qld) (Killoran and McMahon 2014) and Sydney (Adamski 2011).

Such complaints are not new, however, and can be traced back, in the USA at least, to soon after the American revolution (Lubken 2016). While there is a considerable body of work that considers the legal aspects of the dissonance between the freedom of religious expression and communal noise levels (Watkin 1996; Kovačič 2017; Van der Merwe and Blumberg 1998; Haroldson 2015; Weiner 2014; Murdoch 2010; Lloyd 1934; Schwartz 1995), and while there are some studies looking at bells as contributors to historic soundscapes (Garrioch 2003; Burgess and Wathey 2000; Corbin 1998), actual studies of attitudes towards bell ringing are few.

A number of academic studies have examined the acoustic properties of religious structures, such as functional (Desarnaulds et al. 2002; Alvarez-Morales and Martellotta 2015), liturgical (Westermeyer 2009; Prasad 2015), technical (Ansay and Zannin 2016; Álvarez-Morales et al. 2014; Orfali 2007; Orfali and Ahnert 2006; Soeta et al. 2013; Kumar et al. 2008) and workplace safety aspects (García et al. 2019; Felipe Silva and Cabral 2011), the effects of wind direction and strength on sound distribution (Trikootam and Hornikx 2019), and the environmental effects of bell ringing in terms of ground motion (Diaz 2020). At least one study assessed people's perceptions of nighttime bell ringing with regard to sleep disturbance (Brink et al. 2011), while another tried to examine the effects of bell ringing on house prices in the vicinity of churches (Brandt et al. 2013). Several studies have considered bell ringing in terms of its cultural heritage dimensions (Elicio and Martellotta 2015; Suárez et al. 2015; Suárez et al. 2016; Syamsiyah et al. 2018) and the soundscapes associated 
with individual places of worship (Acun et al. 2016; Yilmazer and Acun 2018; Jin Yong et al. 2014; Hong et al. 2010; Zhang et al. 2016) as well as people's perceptions of bell ringing with reference to impression and loudness (Omlin and Brink 2013; Kovačič 2017; Kiser and Lubman 2008), and people's preferences for bell ringing in terms of congruence of the soundscape (Ge et al. 2013). In addition, there have been studies of the histories of individual bells (Fowler et al. 2019) as well as bell-specific sound studies (Salom et al. 2014; Oancea et al. 2010).

There is a need to hear the voices of the actual practitioners and their perceptions regarding what they, their congregations, and their host communities feel. This paper represents the first large-scale assessment of the views of practitioners of five major Christian denominations with regard to bell-ringing practice and its role in contemporary society. While the study focusses on New South Wales, Australia's most populous state, it can be regarded as a snapshot of a liberal secular society of British tradition in the first quarter of the twenty-first century with regular church attendance rates of about 16\% (McCrindle 2019). Canada, New Zealand, and the United Kingdom have similar attendance rates, while the USA has higher attendance rates (36\%) (Pew 2020).

\section{Methods}

To investigate how aspects of aural heritage are valued, a mixed methods study was designed to investigate the use of, and values attributed to bells and bell ringing on church premises in New South Wales. The survey was comprised of a quantitative survey with closed questions soliciting information on aspects such as the presence and nature of bells on premises as well as the frequency and occasion of their use. The findings of the purely quantitative and descriptive aspects are reported elsewhere (Parker and Spennemann n.d.a). These closed questions were augmented by a number of open-ended qualitative questions soliciting opinions and value judgments from the respondents (see Section 2.3). The structure, design, and procedures of the survey followed standard methodology as set out in Bickman and Rog (2008), Dillman et al. (2014), and Sarantakos (2008). The survey was approved by Charles Sturt University's Faculty of Science Ethics in Human Research Committee (protocol number 400/2017/32).

\subsection{Identification of Sampling Frame and Recruitment}

Whilst many religions may broadcast signals to people following their faith, such as bells being rung in both Buddhist and Hindu temples and the call of the Azan from Islamic mosques, this study selected only Christian denominations in order to collect comparable data because of the similarity of Christian church service procedures. The most populous five denominations of the Christian faith were selected according to the 2016 census of Australia (Australian Bureau of Statistics 2017), with these being Roman Catholic (RoC, 37.64\%), Anglican (Ang, 23.68\%), Uniting Church (Uni, 4.43\%), Eastern Orthodox Church (Ort, 3.84\%), and Presbyterian and Reformed (Pre, 3.84\%). Each of these denominational groups is either generally widespread worldwide (e.g., Roman Catholic Church and Eastern Orthodox Church) or based on liturgical traditions from founding organisations (e.g., the Anglican Church of Australia originated from the Church of England and retains and approves Church of England doctrine and principles) (Anglican Church of Australia 2020); with the exception of the Uniting Church of Australia. This denomination is unique to Australia, being formed through a merger in 1977 of Congregational Union in Australia, the Methodist Church of Australasia, and the Presbyterian Church of Australia, with teachings based on the Bible and the Apostles' and Nicene creeds, as well as ecumenism and social justice (The Uniting Church in Australia 2020).

Church contacts were sourced primarily from publicly available sources, such as online diocese/parish and clergy listings. Participant invitations were offered via e-mail or through websites, or by post if the e-mail option was not available, with further contacts identified online through either church listings or a manual search of the Google search engine (Dillman et al. 2014). 


\subsection{Implementation}

The survey was developed in two versions: an online version delivered via SurveyMonkey, and the other being paper-based, requiring manual data entry by respondents (for the full range of questions see Parker 2018). To enable a structured data collection process and to limit survey question numbers, one SurveyMonkey link was generated per denomination (five in total) and emailed to potential participants (1125 invitations). Five versions of a paper survey were also posted, identical apart from the denomination code in the document footer (264 invitations).

If an email invitation was rejected by a mail server, the church was subsequently sent a hard copy survey. If any surveys were received back marked 'return to sender' (12 in total), no further action was taken. A total of 1389 survey forms were disseminated over a two-day period (25-26 November 2017), with subsequent weeks allowing two follow-up email reminders. After observing a very clear trail-off in responses, the online survey was closed on 19 February, with final acceptance date of hard copy surveys being 10 April 2018 (Bickman and Rog 2008). The overall response rate for the survey was $40.1 \%$, with denominational responses varying from high (Anglican $56.1 \%$ and Uniting $41 \%$ ) to low (Eastern Orthodox 12.8\%) (Table 1).

Table 1. Details of surveys sent out and returned.

\begin{tabular}{|c|c|c|c|c|c|c|c|}
\hline & \multicolumn{3}{|c|}{ Electronic Surveys } & \multicolumn{2}{|c|}{ Paper } & \multirow{2}{*}{$\begin{array}{c}\text { Valid } \\
\text { Returns }\end{array}$} & \multirow{2}{*}{$\begin{array}{c}\text { Response } \\
\text { Rate (\%) }\end{array}$} \\
\hline & Invited & Started & Stopped & Sent Out & Returned & & \\
\hline Anglican & 409 & 257 & 10 & 60 & 25 & 263 & 56.1 \\
\hline Catholic & 303 & 100 & 4 & 40 & 12 & 104 & 30.3 \\
\hline Uniting & 226 & 111 & 5 & 84 & 24 & 127 & 41.0 \\
\hline Presbyterian & 123 & 39 & - & 58 & 15 & 52 & 28.7 \\
\hline Orthodox & 64 & 10 & - & 22 & 1 & 11 & 12.8 \\
\hline $\begin{array}{c}\text { All } \\
\text { denominations }\end{array}$ & 1125 & 517 & 19 & 264 & 77 & 557 & 40.1 \\
\hline
\end{tabular}

\subsection{Analysis of Open-Ended Questions}

The survey included a range of free-form questions to elicit the opinions and perspectives of the practitioners with regard to bell ringing (Parker 2018). Five of these are of relevance to the current paper:

- Q1: What are your current feelings/attitudes towards tower bell ringing at your church?

- Q2: How important do you think tower bell ringing is as a form of heritage? (You may consider religious, cultural, historical or other forms of significance.)

- Q3: What do you think is the current feeling/attitude of the congregation towards tower bell ringing at your church?

- Q4: What do you think is the current feeling/attitude of the congregation towards tower bell ringing in your denomination at large?

- Q5: What do you think is the current feeling/attitude of the local community at large towards tower bell ringing in church?

The proportion of respondents who provided answers for free-form comments was over $50 \%$ for all denominations on average, with Orthodox, Presbyterian, and Anglican showing particularly high responses (Table 2). Questions asking about the respondent's attitudes to bell ringing (Q2), the congregation's attitudes to bell ringing (Q5 and Q6), and the local community's attitudes towards bell ringing were very highly represented by comments, indicating a high level of engagement with the topic with an implication that these responses could be considered highly reliable. However, it is important to note that responses to free-form columns are influenced by the personal commitment of the respondent and may not necessarily be fully representative of the church or denomination. 
Table 2. Percentages of respondents who completed free-form comments for each open-ended question.

\begin{tabular}{ccccccc}
\hline Denomination & Q1 & Q2 & Q3 & Q4 & Q5 & n \\
\hline Anglican & 74.9 & 60.5 & 75.7 & 73.4 & 72.6 & 263 \\
Catholic & 68.3 & 55.8 & 64.4 & 59.6 & 65.4 & 104 \\
Uniting & 67.7 & 55.1 & 65.5 & 64.6 & 66.9 & 127 \\
Presbyterian & 80.8 & 59.6 & 76.9 & 78.8 & 76.9 & 52 \\
Orthodox & 100 & 81.8 & 100 & 100 & 100 & 11 \\
\hline Overall & 78.34 & 62.56 & 76.5 & 75.28 & 76.36 & 557 \\
\hline
\end{tabular}

The responses for each qualitative free-form question were grouped by the classifications of denomination, role within church, regionality, and whether there were bells being actively rung on church premises (e.g., Anglican, Church Warden/Lay Priest/Lay Preacher, Inner Regional Australia, Bells rung). A general inductive thematic analysis was then carried out (Sarantakos 2008).

\subsection{Data Manipulation and Coding}

Ternary response attitude questions asked respondents if their attitudes towards bell ringing had changed (response $=$ Yes, No, Unsure), however, $\mathrm{h}=$ they did not ask respondents to identify the direction of that change. Any directional change (positive or negative) was then deduced from the subsequent free-form response inviting reasons for any change, as quantification of data can assist in strengthening qualitative conclusions (Sarantakos 2008). Similarly, open responses from respondents stating their believed feelings and attitudes of the local community towards bell ringing were classified into five categories: very positive, somewhat positive, neutral, somewhat negative, and very negative; based upon the direction and intensity of the reason given. If the respondent stated reasons indicating both positive and negative feelings equally, the comment was classified as neutral.

Church roles were aggregated using the options offered in the survey: Warden (Church Warden/Lay Priest/Lay Preacher), Clerical (Clerical staff/Office Manager), Volunteer (General Volunteer), Congregation (Member of the congregation), Priest/Minister (Priest/Pastor/Minister), and Verger; and by combining the remainder into similar roles to include Bell Ringer, Council (Member of Church Council), and Organist. Further aggregation took place for some analyses forming two categories: Decision makers (Priest/Minister and Council) and Followers (the remainder of the roles).

\subsection{Depersonalisation Protocol}

To depersonalise the citations of free-form responses, all were encoded as: Denomination|Role| Region|bells [not] rung. The sub-coding was carried out as follows: Denomination: Anglican (Ang), Roman Catholic (RoC), Eastern Orthodox Church (Ort), Presbyterian and Reformed (Pre), and Uniting Church (Uni).-_Role: Bell (Bell Ringer/Organist), Clergy (Priest/Pastor/Minister), Lay (Church Warden/Verger/Lay Priest/Lay Preacher), Other (Clerical staff/Member of Church Council/Member of congregation/Office Manager).—Region: GS—Greater Sydney, IR-Inner Regional NSW, OR-Outer Regional NSW, RM-Remote NSW, VR-Very Remote NSW.—Bell ringing was coded as br (bells rung) and bnr (bells not rung)

As this broad coding, e.g., (Ang 5), invariably created the same codes for very different churches it must be stressed that the same code set against responses to different questions does not imply that it is the same individual answering.

Given that a coding, e.g., (Ang 5), is cumbersome, in particular in paragraphs with multiple extracts of responses, the various combinations were further abbreviated as per Table 3. 
Table 3. Lookup list for depersonalisation codes.

\begin{tabular}{|c|c|c|c|c|c|}
\hline Code & $\begin{array}{c}\text { Full } \\
\text { Depersonalisation }\end{array}$ & Code & $\begin{array}{c}\text { Full } \\
\text { Depersonalisation }\end{array}$ & Code & $\begin{array}{c}\text { Full } \\
\text { Depersonalisation }\end{array}$ \\
\hline Ang 1 & Ang|Bell|GS|br & Ang 23 & Ang $\mid$ Other $|\mathrm{RM}| \mathrm{br}$ & RoC 6 & RoC $\mid$ Clergy $|\mathrm{OR}| \mathrm{br}$ \\
\hline Ang 2 & Ang|Bell|IR|br & Ang 24 & Ang $\mid$ Staff|GS|br & RoC 7 & RoC|Lay|OR|br \\
\hline Ang 3 & Ang|Bell|OR|br & Ang 25 & Ang|Staff|OR|bnr & RoC 8 & RoC|Other|GS|bnr \\
\hline Ang 4 & Ang|Clergy|GS|bnr & & & RoC 9 & RoC|Other|GS|br \\
\hline Ang 5 & Ang|Clergy|GS|br & Ort & Ort|Clergy|GS|br & $\mathrm{RoC} 10$ & RoC|Other|OR|bnr \\
\hline Ang 6 & Ang|Clergy|IR|bnr & & & RoC 11 & RoC|Other|IR|br \\
\hline Ang 7 & Ang|Clergy|IR|br & Pre 1 & Pre|Clergy|GS|bnr & RoC 12 & RoC|Staff|GS|bnr \\
\hline Ang 8 & Ang|Clergy|OR|bnr & Pre 2 & Pre|Clergy|IR|bnr & & \\
\hline Ang 9 & Ang|Clergy|OR|br & Pre 3 & Pre|Clergy|IR|br & Uni 1 & Uni|Clergy|IR|bnr \\
\hline Ang 10 & Ang $\mid$ Clergy|RM|bnr & Pre 4 & Pre|Clergy|OR|bnr & Uni 2 & Uni|Clergy|OR|bnr \\
\hline Ang 11 & Ang|Lay|GS|bnr & Pre 5 & Pre|Clergy|OR|br & Uni 3 & Uni|Lay|GS|bnr \\
\hline Ang 12 & Ang $\mid$ Lay $|G S| b r$ & Pre 6 & Pre|Lay|OR|br & Uni 4 & Uni|Lay|IR|bnr \\
\hline Ang 13 & Ang|Lay|IR|bnr & Pre 7 & Pre|Other|GS|bnr & Uni 5 & Uni|Lay|OR|bnr \\
\hline Ang 14 & Ang|Lay|IR|br & Pre 8 & Pre|Other|GS|br & Uni 6 & Uni|Lay|OR|br \\
\hline Ang 15 & Ang|Lay|OR|bnr & Pre 9 & Pre|Other|IR|bnr & Uni 7 & Uni|Other|GS|bnr \\
\hline Ang 16 & Ang $\mid$ Lay $\mid$ OR $\mid$ br & Pre 10 & Pre|Staff|GS|bnr & Uni 8 & Uni|Other|IR|bnr \\
\hline Ang 17 & Ang|Lay|RM|bnr & & & Uni 9 & Uni|Other|IR|br \\
\hline Ang 18 & Ang|Other|GS|bnr & RoC 1 & RoC|Clergy, OR|br & Uni 10 & Uni|Other|OR|bnr \\
\hline Ang 19 & Ang|Other|GS|br & $\operatorname{RoC} 2$ & RoC|Clergy|GS|bnr & Uni 11 & Uni|Other|OR|br \\
\hline Ang 20 & Ang|Other|IR|bnr & $\operatorname{RoC} 3$ & RoC|Clergy|GS|br & Uni 12 & Uni|Staff|IR|bnr \\
\hline Ang 21 & Ang|Other|OR|bnr & RoC 4 & RoC|Clergy|IR|bnr & & \\
\hline Ang 22 & Ang|Other|OR|br & RoC 5 & RoC $\mid$ Clergy|OR|bnr & & \\
\hline
\end{tabular}

\subsection{Statistical Analysis}

The data were analysed descriptively: comparisons were made between respondents from differing denominations, regionalities, roles within the church, as well as grouped by respondents that had or did not have bells on the church premises. Quantitative data were analysed using Statistical Package for the Social Sciences (IBM SPSS Statistics 24). Continuous data were initially explored using the Pearson correlation coefficient; unpaired $t$-tests were used to compare responses between binary variables (e.g., churches with/without bells); one-way analysis of variance (ANOVA) was used when there were three or more groups (e.g., comparing between denominations or roles within the church); and categorical variables were compared using the chi-square test. Statistical significance was set at $p<0.05$, values are reported as proportions, and mean \pm standard deviation.

\section{Results}

There are no known historical data of bell-ringing frequency at any scale in NSW. Such information is important, however, to determine not only the current or past frequencies of bell-ringing practices, but to calculate any change of bell-ringing frequencies over time as this may reflect changes in societal attitudes. As reported elsewhere (Parker and Spennemann n.d.a), the survey of bell ringing found that during the 1990s and 2000s negative and positive changes to bell-ringing frequency almost cancelled each other out, with the exception of Presbyterian churches that reduced or terminated the ringing in a third of their churches. In the past decade (2000s to 2010s), Presbyterian churches reduced the ringing in another eighth of their churches, while one-third of Uniting churches were likewise affected. Compared to that, the bell-ringing frequency among Catholic churches increased by $10 \%$.

As actual positive or negative changes at a church level may not actually determine the amount of bell-ringing frequency change as perceived by the communities, the responses had to be assessed in terms of hours, determining a net change. While there was much variability, an overall net increase in bell-ringing hours over the past 20-year period occurred for Anglican and especially Catholic churches, with minimal change among Presbyterian churches and a considerable loss among Uniting churches. On a regional basis, Anglican churches rang their bells more frequently in Greater Sydney and outer regional NSW, but experienced a dramatic reduction in communities in inner regional NSW, while Catholic churches saw an increase in Greater Sydney and particularly in inner regional NSW. Uniting 
and Presbyterian churches saw a net loss, particularly in outer regional NSW as well as in inner regional NSW (Uniting only) (Parker and Spennemann n.d.a).

\subsection{Current Perceptions of the Importance of Bell Ringing}

In order to identify the significance of bell ringing in both the liturgical and social settings, respondents were asked about feelings and attitudes towards bell ringing from three positions. If bell ringing was found to have great significance to a specific community, denomination, or a regionality bracket, this may then have future implications in any management of this resource. As such, three questions asked respondents about their views of the importance of bell ringing in a church setting: in regards to the services at their church, with reference to their denomination overall, and with reference to bell ringing overall as form of heritage (considering religious, cultural, historical, or other forms of significance). Answers were rated on a sliding scale from 0-100.

\subsubsection{Influence of Denomination}

Respondents across most denominations from churches with external bells rated bell-ringing importance much higher to their church service than those without bells (Figure 1). A correlation between the use of bells and the attributed importance could logically be expected and can be confirmed. The anomaly of the Orthodox rating being high in both churches with and without external bells can be explained by the small number of responses from this denomination, and the use of liturgical bells.

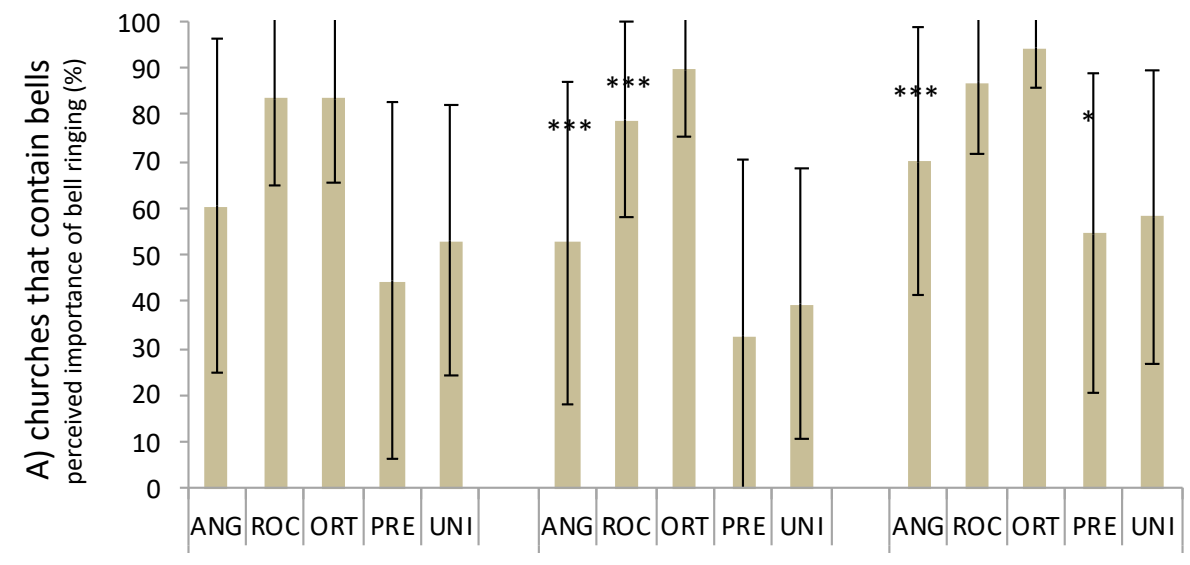

a) importance to service

b) importance to denomination

c) importance as heritage
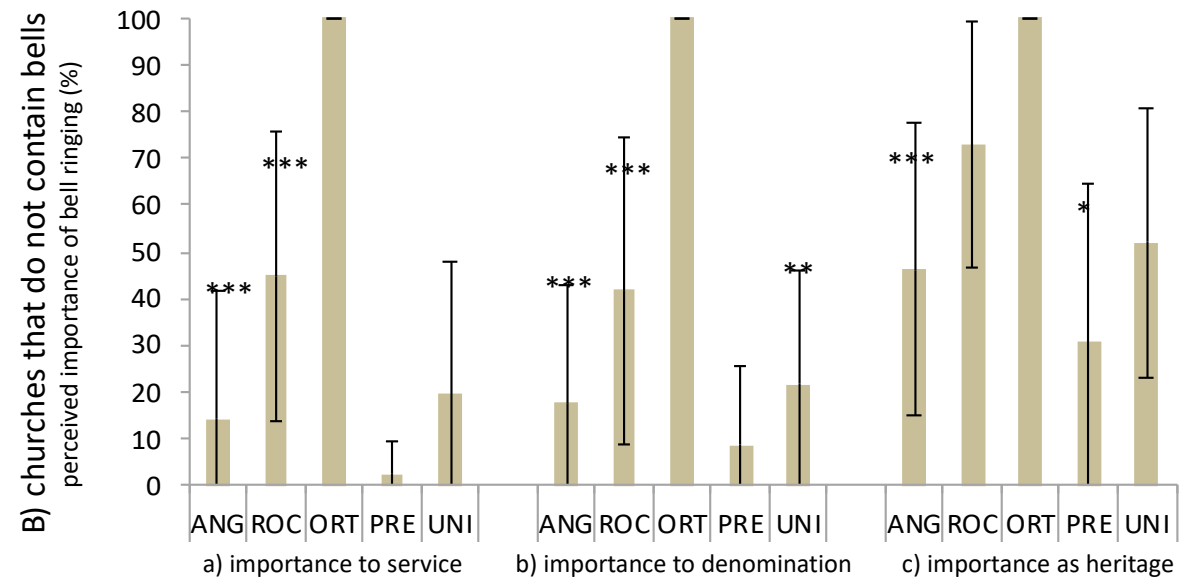

Figure 1. Average perceived importance of bell ringing (a) to the services at your church; (b) to your denomination overall; and (c) as a form of heritage, across all denominations for NSW churches that (A) contain any bells and (B) do not contain bells. Standard deviation bars included, significant differences within that same denomination denoted by: ${ }^{*}$ for $p<0.05,{ }^{* *}$ for $p<0.01,{ }^{* * *} p<0.001$; for churches with bells vs. churches without bells. 
Presbyterian and Uniting churches both attributed low importance of bells to the denomination and to the service, with a slightly higher valuation of bells to heritage, which was particularly expressed among churches that had no external bells. Among Anglican and Catholic churches there was a strong correlation between having bells at the church and a greater importance placed upon bell-ringing importance in a denominational setting.

With regards to regionality, all churches rated heritage as the most important aspect of bell ringing, followed by importance to service. There was also a clear trend of attributed higher importance across all categories from Greater Sydney through to regional and to very remote NSW: as one moves more regionally, the importance placed upon bell ringing increases.

Significant differences exist between the three categories, between location and ratings of importance to service, denomination, and heritage (one-way ANOVA, $p<0.001, p<0.001$, and $p=0.059$, respectively) (Figure 2). Tukey post hoc tests revealed the key differences to be among the perceived importance to service: Greater Sydney vs. outer regional NSW $(p<0.001)$, Greater Sydney vs. very remote NSW $(p=0.002)$, and inner regional vs. very remote NSW ( $p=0.008)$; as well as in terms of importance to denomination between Greater Sydney and outer regional NSW ( $p=0.002)$, between Greater Sydney and very remote NSW $(p=0.016)$. There were no significant differences in the perception of the importance of bells to heritage.

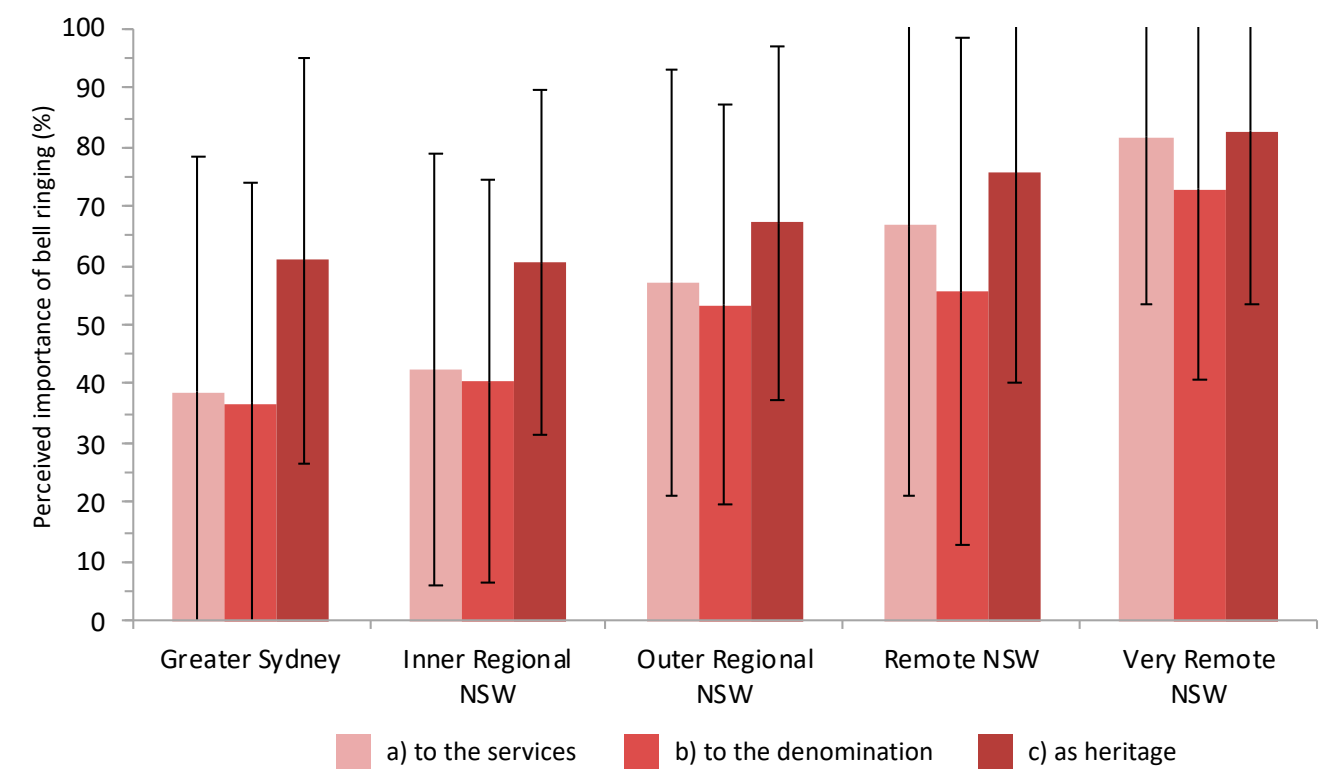

Figure 2. Average rating of importance of bell ringing (a) to the services at your church; (b) to your denomination overall; and (c) as a form of heritage, for all NSW Churches. Standard deviation bars shown.

\subsubsection{Influence of the Number of Bells}

Respondents rated the importance of bell ringing to service, denomination, and heritage differently, depending on the number of bells that were located on the church premises. For Anglican churches, there was an emerging pattern across all three categories where an increase in the number of bells broadly corresponded with an increased importance, certainly up to eight bells. Churches with more than eight bells saw these as less important than those with eight or fewer bells (Table 4).

The importance of the 'eight bells' category can likely be explained by the practice of change-ringing bells, where eight bells correspond to a musical diatonic octave. The melodious call of these bells could be presumed to be recognised and understood more by respondents, potentially inspiring greater importance ratings of this style of bell ringing. This is reflected by the notion of music being a high art form and linked inextricably to Christian theology (Gatty 1848), often discussed by the reformist Martin Luther in the sixteenth century (Buszin and Luther 1946). 
Table 4. NSW Churches' average ratings of importance of bell ringing (a) to the services at your church; (b) to your denomination overall; and (c) as a form of heritage.

\begin{tabular}{|c|c|c|c|c|c|c|c|c|c|c|c|c|c|c|c|}
\hline & \multicolumn{3}{|c|}{ No Bells } & \multicolumn{3}{|c|}{1 Bell } & \multicolumn{3}{|c|}{ 2-7 Bells } & \multicolumn{3}{|c|}{8 Bells } & \multicolumn{3}{|c|}{9 and More Bells } \\
\hline & Avg \pm StDev & Range & $\mathbf{n}$ & Avg \pm StDev & Range & n & Avg \pm StDev & Range & $\mathbf{n}$ & Avg \pm StDev & Range & $\mathrm{n}$ & Avg \pm StDev & Range & $\mathbf{n}$ \\
\hline \multicolumn{16}{|c|}{ (a) Importance to Service } \\
\hline Anglican & $20.97 \pm 33.88$ & $0-100$ & 68 & $54.85 \pm 36.95$ & $0-100$ & 101 & $85.88 \pm 16.04$ & $62-100$ & 8 & $80.14 \pm 18.45$ & $49-100$ & 14 & $72.50 \pm 32.54$ & $17-100$ & 6 \\
\hline Catholic & $58.76 \pm 32.72$ & $0-100$ & 29 & $85.47 \pm 15.59$ & $49-100$ & 38 & $88.00 \pm 16.08$ & $68-100$ & 5 & & & & 81.00 & & 1 \\
\hline Orthodox & $71.50 \pm 40.31$ & $43-100$ & 2 & $83.17 \pm 10.80$ & $71-100$ & 6 & $98.00 \pm 1.73$ & $97-100$ & 3 & & & & & & \\
\hline Presbyterian & $2.87 \pm 6.74$ & $0-30$ & 23 & $51.35 \pm 37.94$ & $1-95$ & 17 & $25.00 \pm 35.36$ & $0-50$ & 2 & & & & & & \\
\hline Uniting & $21.42 \pm 29.56$ & $0-100$ & 73 & $50.84 \pm 28.76$ & $1-100$ & 19 & 76.00 & & 1 & $82.00 !$ & & 1 & & & \\
\hline All & $25.14 \pm 33.91$ & $0-100$ & 195 & $61.47 \pm 34.73$ & $0-100$ & 181 & $81.42 \pm 25.48$ & $0-100$ & 19 & $80.27 \pm 17.79$ & $49-100$ & 15 & $73.71 \pm 29.88$ & $17-100$ & 7 \\
\hline \multicolumn{16}{|c|}{ (b) Importance to denomination } \\
\hline Anglican & $25.03 \pm 32.65$ & $0-100$ & 58 & $48.70 \pm 35.31$ & $0-100$ & 94 & $56.00 \pm 30.68$ & $0-88$ & 8 & $69.92 \pm 20.42$ & $31-100$ & 13 & $54.86 \pm 38.83$ & $1-100$ & 7 \\
\hline Catholic & $56.03 \pm 34.21$ & $0-100$ & 30 & $80.50 \pm 19.17$ & $37-100$ & 36 & $79.40 \pm 19.36$ & $56-100$ & 5 & & & & 82.00 & & 1 \\
\hline Orthodox & $80.00 \pm 28.28$ & $60-100$ & 2 & $90.00 \pm 11.22$ & $71-100$ & 6 & $99.00 \pm 1.73$ & $97-100$ & 3 & & & & & & \\
\hline Presbyterian & $8.17 \pm 16.32$ & $0-63$ & 23 & $36.56 \pm 40.17$ & $0-100$ & 16 & $33.00 \pm 24.04$ & $16-50$ & 2 & & & & & & \\
\hline Uniting & $23.03 \pm 25.31$ & $0-91$ & 65 & $34.94 \pm 27.05$ & $0-100$ & 16 & 77.00 & & 1 & & & & & & \\
\hline All & $27.97 \pm 32.11$ & $0-100$ & 178 & $54.52 \pm 35.54$ & $0-100$ & 168 & $67.63 \pm 29.71$ & $0-100$ & 19 & $69.92 \pm 20.42$ & $31-100$ & 13 & $58.25 \pm 37.21$ & $1-100$ & 8 \\
\hline \multicolumn{16}{|c|}{ (c) Importance to heritage } \\
\hline Anglican & $48.26 \pm 32.64$ & $0-100$ & 61 & $66.60 \pm 29.62$ & $0-100$ & 92 & $78.89 \pm 22.79$ & $38-100$ & 9 & $87.00 \pm 14.41$ & $56-100$ & 14 & $83.40 \pm 15.21$ & $63-100$ & 5 \\
\hline Catholic & $76.22 \pm 22.68$ & $0-100$ & 28 & $88.36 \pm 14.99$ & $50-100$ & 36 & $91.80 \pm 7.76$ & $83-100$ & 5 & & & & 95.00 & & 1 \\
\hline Orthodox & $94.00 \pm 8.49$ & $88-100$ & 2 & $93.00 \pm 10.55$ & 74-100 & 6 & $99.00 \pm 1.73$ & $97-100$ & 3 & & & & & & \\
\hline Presbyterian & $31.29 \pm 32.56$ & $0-100$ & 24 & $59.18 \pm 36.22$ & $0-100$ & 17 & $45.00 \pm 7.07$ & $40-50$ & 2 & & & & & & \\
\hline Uniting & $53.21 \pm 29.00$ & $0-100$ & 61 & $53.82 \pm 33.35$ & $0-100$ & 17 & 75.00 & & 1 & & & & & & \\
\hline All & $52.50 \pm 32.41$ & $0-100$ & 176 & $70.16 \pm 29.96$ & $0-100$ & 168 & $81.55 \pm 21.36$ & $38-100$ & 20 & $87.00 \pm 14.41$ & $56-100$ & 14 & $85.33 \pm 14.40$ & $63-100$ & 6 \\
\hline
\end{tabular}


It is important to note that the importance of bells to service was regarded as high among Catholics, even if their church did not have an external bell. Setting aside the responses from Orthodox churches due to their small number, average values attributed by Catholic respondents are much higher, but not significantly so. The same applies to the other denominations for importance of bells to service as well as for importance of bells to denomination and heritage.

\subsubsection{Influence of the Diocese}

Many free-form responses noted that attitudes of the congregation towards church bell ringing within Anglican denominational boundaries might have been affected by the diocese. Specific theological leanings appeared to permeate bell-ringing importance to the many churches within a diocese, as exemplified by the comments that "across this denomination it would rate highly, across this Diocese I think it would rate lowly" (Ang 5), and that "the diocese of which we are part of is strongly evangelical-the 'traditions of men' (i.e., bell ringing) are secondary to the things of the Bible in our diocese" (Ang 9).

Specifically, the Anglican Diocese of Sydney was mentioned, with respondents clarifying that this Diocese "only values the preached Word and disregards cultural aspects of our churches" (Ang 5), that it is "renowned for eschewing anything that doesn't help people know Jesus better-I think bell ringing falls into that category" (Ang 4), and that in the Sydney Diocese "bell ringing takes a low priority, if rung at all" (Ang 11). Interestingly, one respondent stated that "on a national level, I think you would find a much more positive attitude to bell ringing - outside the Sydney Diocese the percentage of high church and Anglo-Catholic churches is much higher so they naturally tend towards ceremony and ritual rather than a focus on teaching, which we have in Sydney" (Ang 7). This divergent view of bell-ringing importance poses an interesting question: is interest (or lack thereof) in ceremony and ritual-centred bell ringing of an individual church primarily motivated through diocese directive, or through the inclinations of individual church leading figures within the diocese?

\subsection{Perceived Views of the Local Community}

Respondents overall gave a strong view that the majority of the local community have a neutral or ambivalent attitude towards church bell ringing (Table 5), with an abundant use of terms such as "ambivalence", "indifference", and "neutral" in the free-form columns. However, there were many respondents who gave mixed opinions on the matter, offering a multitude of views of a complex situation.

Perceived positive community attitudes of church bell ringing were more than twice as prevalent as negative attitudes, with free-form comments declaring that ringing bells are "a joy to hear" (Ang 24), "a largely unobtrusive reminder of some potentially happier time in the past" (Ang 16), and "psychologically a comfort to people" (Pre 5). Some respondents suggested that the "ringing of bells reminds people that the church is alive and active" (Ang 19), "gives them a sense of Europe" (RoC 12), or "the feeling of a village" (Ang 7). Many had received feedback from their community that "people miss them when they are not rung" (Uni 11) and that while the sound does not necessarily have religious connotations, "hearing bells ring is joyful and sentimental ... something nice to hear" (Uni 5).

Some positive comments were centred around smaller subsets of the community, suggesting that particularly the very young and elderly populations place greater importance on bell ringing. Comments include "One elderly lady used to open her windows and doors when we were ringing and she'd phone her friends and get them to listen to the bells as well!" (Ang 1), "Young children seem to like them, and so do parents" (Ang 5), and "Older generations would appreciate it as part of the culture they were raised in" (Ang 9).

However, there were also many negative responses, including that the community would "hate it-it intrudes into their lives" (Uni 1), be "hostile" towards bell ringing (Ang 8), or simply be annoyed: "I think they'd rather not be woken up on a Sunday morning" (Ang 4). Responses indicated that the community "would find it noisy" (Ang 4), that "churches get noise complaints for trivial noise let 
alone bell ringing" (Pre 1), and that "bell ringing would 'disturb the peace' and cause the community to get angry with the noise of the bells ringing early on a Sunday" (Ang 4).

Many respondents suggested that negative views of bell ringing have a deeper social connotation, that "there has been a rapid change in attitude towards churches recently in our society-we have moved from acceptance to tolerance, to aggressive opposition" (Ang 5), that "many complaints are often more anti-religious than anti-bell, but use the bells as an outlet for their frustration" (RoC 9), and that "a small number of anti-religious people would probably object and most likely succeed in suppressing the use of the bells" (RoC 2). Some took a particularly dim view of the local community's views towards bell ringing: "After the royal commission [into Institutional Responses to Child Sexual Abuse, ed.], sell the bells and give the proceeds to the victims of abuse" (RoC 2).

Interestingly, the majority (75\%) of negative assumptions about the community's attitudes originated from churches where bells were not to be found on the premises at all, with only around $16 \%$ negative comments derived from churches currently ringing tower bells. While it could be supposed that this could simply be attributed to personal bias on behalf of the respondent, comments suggested that another factor is also at work. It appears that numerous churches that actively ring bells recognise the potential problems that ringing may entail with the local community and take measures in attempt to counteract or minimise these.

Comments supporting this notion included: "We take great care not to overdo it with our bell ringing" (Ort), "Through a combination of sensible ringing times and adequate sound controls for prolonged extraneous ringing, acceptable compromises can usually be made to satisfy both parties" (RoC 9), "We try to be considerate towards our non-Christian neighbours" (Ang 5), and "We are careful to stay within the guidelines of the local council" (Ang 1). In some cases it appeared that religious doctrine became subservient to the communities' views: "If we were to ring the bells as we would like to, the community would be unhappy" (Ort). Some congregations enabled at some level of compromise to ensure ongoing bell ringing continued: "The local community were not happy with The Angelus ringing at 6am but were okay with the midday and 6pm ringing, so this is what happens-compromise" (RoC 2).

Interestingly, one respondent stated that "we have now become so used to 'no bell' that it is not missed" (Uni 8), indicating that attitudes (and change in attitude) towards bell ringing may be largely dependent on whether the individual experiences bell ringing on a recurring basis.

Aggregating all local community-related free-form responses into a five category scale (Table 5), Anglican and, in particular, Catholic respondents were far more positive about bell use than Uniting Church and Presbyterians. The latter were by far the most neutral, which can also be interpreted as ambivalent.

Table 5. Attitudes of the local community towards church bell ringing (in \% by denomination), classified into five categories based on free-form responses.

\begin{tabular}{ccccccc}
\hline & Very Positive & Positive & Neutral & Negative & Very Negative & n \\
\hline Anglican & 6.82 & 30.68 & 44.89 & 14.77 & 2.84 & 176 \\
Catholic & 3.39 & 44.07 & 42.37 & 10.17 & 0 & 59 \\
Orthodox & 0 & 20.00 & 40.00 & 40.00 & 0 & 10 \\
Presbyterian & 0 & 14.71 & 67.65 & 17.65 & 0 & 34 \\
Uniting & 2.86 & 27.14 & 51.43 & 17.14 & 1.43 & 70 \\
\hline All & 4.59 & 30.37 & 47.85 & 15.47 & 1.72 & 349 \\
\hline
\end{tabular}

\subsection{Changes in Attitude towards Bell Ringing}

There are no known historical data of any individual or community attitude change to bell ringing at any scale in NSW. This information is important to determine not only if there have been any changing attitudes towards bell-ringing practices, but to calculate any magnitude of this change. Questions in the survey asked the respondents of any personal attitude changes and offered free 
responses to justify their positions of why or why not their views have/have not changed with reference to bell ringing as an activity. An open question also invited the respondents to offer their considered opinions of how their community might feel towards bell-ringing activity at churches.

Of the 439 respondents who responded to the initial question of attitude change, the majority $(64.7 \%)$ stated that their views on bell ringing had not changed over time. Almost a quarter of the respondents (23.92\%) acknowledged an attitude change, and $11.4 \%$ stated they were unsure. Over $70 \%$ of respondents who acknowledged change justified their answers with free-form statements, with the majority of these discussing reasons for a positive attitude shift (around $60 \%$ ). There seemed to be a strong correlation between a positive attitude shift and bells being actively rung at the church, and a negative attitude shift at churches without bells or with inactive installed bells (Table 6).

Free-form comments justified positive attitude shifts for many reasons. Common motivations included simply a greater awareness of bells and bell-ringing practices later in life: "My eyes and ears have really been opened up to what's involved and the amount of work that goes into the art" (Ang 16), "Scant knowledge of make and mechanics of ringing until our bells were installed" (Ang 3), and "I did not experience bells much before they were installed in my church, enthusiasm came with learning to take part" (Ang 19).

Table 6. Changes in attitude towards church bell-ringing activity (in \%).

\begin{tabular}{ccccc}
\hline & Positive & No Change & Negative & n \\
\hline Bells rung & 32.61 & 60.87 & 6.52 & 138 \\
No bells/bells not rung & 8.76 & 71.53 & 19.71 & 137 \\
\hline
\end{tabular}

This seems to reinforce the notion that the presence and use of bells increases the appreciation, while an absence of bells increases disinterest and apathy. When bell ringing stopped, or the person moved to parish where bells were not rung, respondents experienced feelings of loss: "Now I'm in a parish without them, I miss them" (RoC 12) and "As the use of church bells has decreased I have come to appreciate them more" (RoC 3 ).

For some respondents, intergenerational change was of concern, as reflected in these two statements: "As I have become older I appreciate many things that I took for granted in my youth" (Ang 12) and "As an adult I have a more spiritual sense about them" (RoC 11).

Some respondents saw bell ringing as a means of public affirmation of their spiritual identity and as a way to ensure that churches actually remain valid in a changing world. This is well exemplified by these three statements: "As society has moved away from Christian heritage, the bell ringing plays a helpful reminder to us of that heritage" (Ang 5), "We have become more aware of the diversity in Australia. We need to preserve the right to practice our faith and traditions" (Ang 5), and "Whatever way we can make the presence of God and his people felt in a world where he is increasingly marginalised has to be a good thing" (Ang 9).

For some respondents, intergenerational change was a cause for concern: "As newer generations settle for less engaged technical substitutes or simply 'don't bother', I think it is nice to contribute to enriching the soundscape" (Ang 16). Societal change was also a catalyst for inciting a negative attitude shift: "As society has become more multicultural and more secular, churches have lost their role as a focus in the community" (Ang 5), "Church attendance is dropping" (Uni 3), and "I think in the past the bells were a call to worship but not so much today" (Ang 25). Some respondents believed that bell-ringing activities should even continue to change alongside societal change: "Now we are encouraged to be tolerant of others-as a compromise I would prefer to have limited bell ringing" (Ang 1).

Other negative attitude shifts resulted from theological ideology: “A more mature understanding of liturgical celebrations has led to more personal means of engaging with the liturgy rather than using outside devices" (RoC 8) and "I've grown to question or doubt the cultural relevance of bell ringing when our purpose is to bring the gospel to our culture" (Ang 9). On a very different level, 
some respondents recognised emerging problems with training and retaining bell ringers: "loss of people with skills to play bells" (Uni 4) and "difficult to maintain a band of willing and able people to ring bells" (Ang 3).

\section{Role of Church Bells in Modern Society}

\subsection{Religious Overtones}

Bells have been used for religious purposes throughout history (Kovačič 2006; Hernandez 2004; Kovačič 2009; Arnold and Goodson 2012), and, as expected, there were numerous comments highlighting the roles church bells play in religious settings. Free-form comments suggest that some denominations express a more united view of the role of bells and others are largely divergent within the denomination.

Catholic churches seemed largely unified with regards to the role of ringing, with most comments stating that in Catholicism bell ringing has a "great tradition" (RoC 5), "connects us back 2000 years to all who came before and with other Catholics internationally today" (RoC 12), that the sound of bells "is an integral part of our liturgy and life" (RoC 6), and lets people know that "we are here and open for business" (RoC 6). One church also commented that during the major services at Easter and Christmas "people bring in their own bells and ring them" (RoC 4) when the church bell rings. Other comments suggest that the traditional Catholic view is not only strong but growing, noting that "there is now a resurgence amongst the younger generation for all of the traditions of the Catholic faith" (RoC 3).

Similarly, the Orthodox Church seemed to have a united view of the indispensable role of bells in the church setting, with comments stating that bell ringing is "one of the most important aspects of our worship gatherings" (Ort) and that a "church is not a church without a bell" (Ort). In this denomination bell ringing has deep religious symbolism (Aldoshina and Nicanorov 2000; Burnett 2002), with church regulations prescribing "in detail how and when bells should be used" (Ort) and the resulting sound of bells being "a symbol of the voice of God" (Ort).

The Uniting Church, on the other hand, appeared to have a cohesive view that bell ringing is not necessary in church or religious practice, with respondents stating that "in the uniting church overall the focus is more on people and interaction than [on] ceremony" (Uni 5), that bells are "irrelevant to our denomination as it's not our culture" (Uni 2), and that bell ringing "isn't raised in any internal monthly writings" (Uni 12). The strong focus on people in the Uniting Church was highlighted by the comment: "Even though we worship in a beautiful old building our value is placed far more on the church being the people, and we would be happy to meet in a public hall or wherever would best accommodate the people in the future" (Uni 10). This strong view may have had some unintended negative consequences, as in one church, "a wealthy benefactor withdrew himself and bequest funds from our church because bells were not installed in the bell tower" (Uni 4).

Presbyterian churches seemed to also have a mostly unified view that bells are actually superfluous, unnecessary, and "contextually irrelevant" (Pre 6). Comments suggest that "bell ringing was never a big deal in the Presbyterian Church. This is due to its philosophy or theology of worship" (Pre 2), that "nobody discusses it at our week-long assembly" (Pre 1), and that bell ringing "is a religious observance only and doesn't save anyone" (Pre 6). However, it was recognised that bell ringing plays a role in some churches, as "different congregations within the Presbyterian Church have different attitudes towards bell ringing" (Pre 9) and that the bell has a "precise outreach to the community, being one of the few things that the outside world hears" (Pre 8).

Anglican churches were the most dichotomous with reference to the roles of church bells at individual churches, depending on whether the individual church was considered 'high' or 'low' in nature: "Bell ringing is often associated with the 'Catholic' end (as opposed to the 'evangelical' end)" (Ang 7) or "Being on the lower side of churchmanship, most people are not concerned with bells" (Ang 6). The clergy's approaches to bells differed, depending on their standpoint. While a practitioner asserted that a bell's "wordlessness means that it doesn't serve to pass on a message or communicate 
apart from sounding nice" (Ang 4), another mused that he had "reflected on and developed the gospel opportunities it presents" (Ang 7).

Some Anglican churches took the pragmatic approach towards the role of bells, regarding them as "not something to invest in as it's unlikely to win converts" (Ang 5), and not significant to some churches "dealing with bankruptcy and trying to expand the congregation and thus income, ... focusing on contemporary style services and hopefully attracting youth and family groups" (Ang 3).

For those on the 'higher' end, bell ringing was directed by the 1662 Book of Common Prayer (Church of England 1762) requiring bells "to be rung to alert the community to the start of worship and let them know prayer has been offered" (Ang 9), creating a "strong and lengthy Anglican tradition" (Ang 3). Here, church bell ringing was often viewed with highly religious symbolism: "I ring the bells as they were rung in the monastery-3 3 , Father, Son and Holy Spirit, birth death and resurrection-so each ring has symbolic meaning" (Ang 9), and "our single bell is rung 33 times five minutes prior to our main service, and at the end of the funeral, once for each year of the deceased's life" (Ang 5).

Often these divergent views were reported with an air of derision from both parties. The opinion that "tradition is a bit like discipline, it gives us structure and boundaries and stops us from becoming unstructured happy-clappy, rafter swinging Pentecostals in which the call to revere God goes out the window" (Ang 9) contrasts well with the view that "evangelical churches are not primarily concerned about preserving traditions. They are concerned about preserving the good news of the historical eyewitness accounts of the death and resurrection of Israel's Messiah and they do not wish anything to cloud that reality" (Ang 4).

Some respondents mentioned that even liturgy-specific church bell roles can deviate within and between churches: "There was a short period in the church's history (in the late 70s) when the clergy wanted the bell rung at the time of the consecration of the bread and wine but that was discontinued when a new rector with different ideas arrived" (Ang 14), and "Tower bells are always ok, but altar Sanctus bells can be very controversial" (Ang 7).

\subsection{Change-Ringing}

Interestingly, one respondent mentioned that "the ecumenism of change ringing within NSW probably shouldn't be ignored" (RoC 9), suggesting that bell change-ringing has the potential to link churches across many denominations through its practice. However, as results show that bell ringing was generally rated of high importance by those who were in a connection with current bell activity (and vice versa), the ecumenical function of bell ringing might be somewhat limited to those who are actively or openly involved.

Many comments pertained to the activity of change-ringing bells and towards the bell ringers themselves. At a secular level, bell ringing is "very important to the bellringers ourselves, as we take our activity seriously" (Ang 3), promotes "positive interaction with people and provides a definite camaraderie among ringers and in particular develops a sense of belonging to and being a part of the world-wide family of bell ringers" (Ang 1), and is "a great physical and mental exercise, socially very rewarding - a great group of supportive friends, and gives a sense of service to the church and community" (Ang 1).

The activity of bell ringing could be therefore comparable to any other community group and was often associated with people either of no faith or from other congregations: "I am not religious but love bell ringing" (Ang 2) and "The congregation has an ageing population so recruitment is often done outside the congregation" (Ang 12). Like any community group, they were united by the activity undertaken: "Returning home and ringing our church bell I feel a bond between all bellringers past and present" (Ang 12), and often entirely self-sufficient: "Fund raising for maintenance and upkeep of the bells is done entirely by bell ringers without the assistance from the Cathedral treasury" (Ang 12).

Respondents outside of the bell ringing community often mentioned their interest in bell change-ringing as a secular art form: "It is an ancient art-a highly developed skill and a significant musical form" (Ang 6), "It is a particular form of music ... It unites a community in sound" (RoC 1) 
and "Music should be encouraged as should the arts in general" (Pre 5). However, some respondents recognised that the secular nature of some ringing is discordant with the workings of the church: "Most bell ringers are not members of the congregation and only interested in their hobby creating distance between ringers and the church" (Ang 14).

\subsection{Role of Bells in Secular Life}

It is interesting to note that there were many comments from respondents referring to the role of bells in secular life, as this suggests that bells and bell ringing are important and have meaning even to those outside the church and its congregation. Bell ringing is also popular with acts of ceremonial society (both secular and religious), as churches often receive requests to ring the bells at weddings where "many of these couples are not regular members of the congregation but love the idea of bells" (Ang 12), and "I know of modern brides who choose to marry outside their own parish churches to use a church which had bells to ring" (RoC 12).

As well as these purposes of ringing bells, many respondents noted that bells are often rung as part of a purely secular society. As "a form of recall to remembrance or memory of events for the community" (Ang 7), bell ringing was noted to "have been associated with some of the most significant events in history, ringing out at the end of World Wars, royal coronations, births, deaths and marriages of famous people and as a community message of peace" (Ang 19). Indeed, some of these events have been recorded and distributed as gramophone records (e.g., His Master's Voice 1946).

Respondents opined that the sound of bell ringing "gives a sense of stability and peace" to the wider community (Uni 9), or for those who are "not faithful to perhaps stop and pause in the busyness of life" (Ang 5), and creates a sense of remembrance for the community for those bells that were "donated in memory of loved ones" (Ang 24).

The importance of bell ringing in secular society could be summated by the following two statements: that there is "nothing nicer than hearing bells particularly in Adelaide when watching the cricket" (Uni 1) and that the researcher should "make a list of the songs that refer to the bells ringing/chiming" (Uni 6).

Bell ringing activity on church premises does not serve as a purely religious function, and even if the ringing is being undertaken on purely religious symbolic grounds, there are many people in the community who may perceive this activity secularly, attributing their own meanings and significances towards these sounds as a result.

\subsection{Bells as Heritage}

Bells were also noted to have been an "important means of communication before phones and the internet or reliable clocks" (Ang 20) and in one case the "urgent ringing of the school/church bells warned of fire before the electric alarm" (Ang 16). Practitioners gave divergent, but primarily positive views on opinions of bell ringing and heritage significance, suggesting that there is widespread opinion of high importance towards bell ringing as religious, cultural, historical, and social heritage. These can be grouped into the concepts of the bell sound itself, cultural heritage, and religious significance.

\subsubsection{Historical}

The importance of the historical element of heritage was frequently observed, as expressed in sentiments like: "Given that the church bell has been rung since 1877 I think it is an important form of heritage" (Ang 22). Some contended that "bell ringing is a part of our history and so is part of our heritage" (Uni 10), and "bell ringing shows great history and previous importance in religious settings, even if we don't see it as high importance today" (Uni 7) and thus argued that it should be preserved. Furthermore, this history provides a catalyst towards classifying bell ringing as heritage: "Part of our Anglican heritage that should not be lost" (Ang 12) and "Historically it may have had more significance ... for certain buildings it may be worth preserving some sort of bell ringing" (Uni 1). 
Some respondents discussed aspects of heritage management: “To maintain the heritage nature of any building with any heritage significance in Australia is very important to our wonderful country and the retaining and use of church bells is equally important" (Uni 8) and "Our Diocese has completed a heritage register for all churches and this has included the various bells" (RoC 6). Some respondents discussed the complex nature of heritage, with bells being a symbol of one aspect of a subculture: "I do think that religion is of deep cultural significance, although now unfashionable. Sometimes the look of a beautiful church and the sound of the bells are the only thing the outside world sees and hears" (Pre 8).

The complexity of heritage was clearly apparent to some respondents, which suggests that the importance of heritage may be of highly significant concern to some churches. One respondent recognised the cultural heritage of bell ringing despite having no perceived religious connotations: "We are a heritage church which stands us apart from our counterparts. The bells go with the stained glass windows, pipe organ and Gothic design. There is no theological significance, only cultural" (Pre 3).

\subsubsection{Tradition}

Many respondents discussed the tradition of bell ringing and how, in their view, this was a foundation for considering this activity as heritage. Respondents stated that bell ringing is a "reminder of continuity" (Ang 1), that it is "a tradition which is becoming lost" (Ang 13), and "centuries old traditions are the stability of modern-day life" (Ang 11), with the ultimate view that "traditions are worth hanging on to" (Ang 11). Even when traditions and times change, and as church membership declines, "these important practices are a reminder of the traditional role and presence of the local church in the community" (Uni 7) and that "it's our heritage and a legacy being kept up" (Ang 23).

Such traditions seemed strongly apparent in regional areas, perhaps explaining the higher importance placed on bell ringing in these locales. Comments in rural communities expressed that "the bells are a part of the church like any church furniture" (Ang 9) and that "communities need to protect, share and celebrate their local heritage" (Ang 9).

However, some respondents reflected that traditions alone do not form a basis for heritage, as the "progress of time swallows some practices of the past" (Ang 15), and that tradition "has lost its place and significance for younger people in the community and in most church congregations in this area" (Ang 4). They could see the changing tradition of bell ringing due to societal changes, but noted that making an effort to preserve this tradition may be worthless: "Cultural practices change all of the time, some we choose to remember personally, others institutionally or culturally. It served a purpose during a particular period of history. In our context it no longer serves that purpose. I don't consider it to be so institutionally or culturally significant that it should be institutionally preserved" (Ang 6), and that, although heritage is a great thing, "I wonder though if it can be appreciated without it needing to be continued especially just for the sake of continuing it. The best heritage still 'rings' true for what helps today" (Ang 8). This gives rise to the question of functional heritage vs. historical heritage, with respondents clearly supporting both sides of this issue.

\subsubsection{Sound}

Some respondents mentioned the importance of the actual bell sounds as heritage, noting that bell sounds "enrich the ambience of the town" (Ang 9) and that "the ringing of bells to announce services of worship and celebration of marriage, baptisms and confirmation, and the tolling of bells at funeral services, remains a widely accepted/welcome addition to the urban soundscape" (Ang 17).

Yet, there were other diametrically opposed views: "It's not an aspect of heritage that many people enquire about nor document-so I suspect it is not important to most people" (Ang 8). Some considered heritage as mostly incompatible with the central sacred function of the church. This was apparent in comments stating: "Too often I find heritage items more of a hindrance than a help to our mission to make the good news of Jesus known. We want to be a movement not a museum!" (Ang 4), "I'm not interested in the church being a custodian of cultural heritage. That is not our agenda" (Ang 7). 
Some respondents, however, implied a sense of religious heritage in this regard, with bell ringing reminding people that the "heritage building in their midst is actually a functioning ministry centre" (Ang 5). Others clearly discussed the importance of sound in general as heritage: "Sounds are as much a part of our heritage as aesthetics in architecture" (Pre 10) and "History and heritage is not just what's visible: it is also what is heard" (RoC 3); and others gave compelling reasons why sounds should be considered as important: "Sounds evoke memories. Memories are the basis of heritage. Bell ringing accompanies people in all the most important events of their lives: their worship, marriage, death, prayer, special occasions, news of death etc." (RoC 6), and that "removing them would be like silencing a whole community and its history and contribution to Australian life" (Ang 5). These responses suggest that it is the actual intangible auditory sound of bells that has heritage significance rather than the activity of ringing them, although they are closely tied together.

\section{Implications}

The broader general public associates church bells with Christianity and religious service. The bells survey, however, found that just because all churches belong to the Christian faith, it does not imply that all treat their bells, and their use, in the same way. Rather, the survey showed great diversity of degrees of importance placed on bell ringing across the denominations. Reasons for the different bell distribution and ringing frequency can be ascertained based on the history, depth of liturgy and sense of embodiment in denominational practice.

The ritual use in practice of a material culture such as the tolling of a bell allows a common exchange of assurance that each member of the church and congregation is part of a group. Such a sense of embodiment is a powerful characteristic of religion, developed when a social body is constructed through a collective reality of individuals undertaking parallel motions, such as recitations, liturgies, or ritualisations (Morgan 2009). Furthermore, the utilisation of a symbol brings about an emotional sensed reality of a moral community experience for those involved, with the symbol used retaining the emotional charge long after the event has terminated (Mellor and Shilling 2010). Through an awareness of our interconnectedness into a transcendental reality, embodied perception becomes a spiritual experience (Jones 2019), thus denominational differences of liturgy and embodiment of faith may explain the differing levels of spirituality bestowed on the act of church bell ringing.

The sound of church bells has both public and private elements, being designed for both liturgical ringing practices and for wider public broadcast. However, depending on the intensity of the sound, both of these public/private sounds can effectively intrude into the private lives of residents of the nearby community, generating many issues regarding sound emanation.

Throughout history, the ringing of church bells has been imbued with both sacred and secular symbolism (e.g., nineteenth-century France, Corbin 1998). As secularism increased in many liberal western societies (Crockett and Voas 2006; Goujon et al. 2007; Skirbekk et al. 2010), albeit not in geographically uniform fashion (Dunn and Piracha 2015), the sacred symbolism of bell ringing as a very public expression and affirmation of faith has diminished. At the same time the increasing ubiquity of personal time keeping devices (watches, cell phones) has often reduced the secular role of the ringing of church bells to public celebratory occasions (Parker and Spennemann n.d.a). Some of these public occasions combine secular and sacred symbolism, such as in bells rung to commemorate ANZAC Day in Australia and New Zealand or to commemorate the end of WWII in Europe. In some instances, bells are used to publicly mark personal life stages (e.g., marriage or death), where the symbolism of the sounds resonates with the wider community, whether confessing to a faith or not.

Faced with explicit or implicit pressure from the secular elements of society, some churches have had local government authorities place restrictions upon their bell-ringing activities, including decibel, frequency, and temporal limitations. In this the situation in NSW is not unique as examples from numerous other countries attest (see introduction for references). The churches thus affected include both contemporary and historic buildings. 
These imposed limitations present an issue for three central reasons-changed sound events can directly and indirectly affect church religious practice, the church community, and the surrounding community.

As the liturgy of bell ringing is strong in many Anglican and Catholic churches and very strong in the Orthodox Church, imposed sanctions on emanated sound from church bells represents a constriction of the freedom of religious expression and custom. Central to this is the dissonance between the rights of an individual, or a segment of society, to religious expression as balanced against the rights of other segments of society to tranquillity in their auditory environment, with the solution often adjudicated in courts and tribunals. With the dissonance or conflict framed by and restricted to these terms other dimensions are easily overlooked or purposefully ignored.

Limitations imposed due to complaints from nearby residents not only affect the functional liturgical component of bell ringing, they also affect the sound heritage that can be attributed by the community. Entirely silenced in this polarized discussion are other members of the community who perhaps appreciate bell ringing and consider this to be an integral part of the soundscape of their community. For some communities bell ringing, be it the sound of the tenor bell or a peal on specific occasions, represents a soundmark, the distinctive 'landmark of sound', which, once identified, "deserves to be protected, [as it] makes the acoustic life of the community unique" (Schafer 1994, p. 10). Yet heritage and familiar soundscapes can possess social value to particular communities (Parker and Spennemann n.d.c) and provide a connection to our environment (Dumyahn and Pijanowski 2011b), evoke emotional responses (Cain et al. 2013), and thus have mental health benefits (Aletta et al. 2018).

Ceasing bell-ringing activities potentially extinguishes such soundmarks from the urban soundscape. Elsewhere we have argued that such sound loss is analogous to the extirpation or extinction of a species within the natural environment- the sound is no longer heard or experienced in its original setting at a specific location (extirpation) or universally (extinction) (Parker and Spennemann n.d.c).

Most serious in this regard are changes to bell-ringing practices based on decision makers second guessing the attitudes and expectations of their host communities. Some examples have been noted above. While this is beyond the scope of this paper, we want to highlight the extraordinary power that individual priests or bishops hold in determining the future of the heritage of sounds and soundmarks, even though they, by and large, lack training in heritage management.

So, what if the church itself limits functional bell-ringing activity through administrative changes, through the transition from a traditional-based faith to contemporary views, or through a transition to recorded rather than traditional acoustic bell sounds? One would assume that in most cases liturgical heritage is not affected. After all, comments suggest that bell ringing is only viewed as important to a religion if is dictated by the religion itself. But heritage attributed to church bell ringing by both the church community and the local community would be still affected. The sound events would be altered in frequency and duration, changing the local soundscape in the process. To add further complexity, what if the congregation of a specific church were to decline below such critical mass as to not be able to justify the maintenance and existence of the church building (and any associated bell ringing), with the church ceasing to operate at all? In such a case, the church community does not exist, so both liturgical heritage and heritage attributed by the church community can no longer be considered, leaving only the surrounding community's values being affected.

This raises an interesting and important question, and one that potentially has major implications when dealing with future management of sound in the environment: who owns this sound heritage? If the emanated sound is predominantly functional, should greater ownership be given to the church community? However, it is entirely possible that members of the community surrounding a Christian-faith church can place such high heritage value on bell sounds emanating from the church that a sense of 'ownership' is placed on these sounds by these community members. Thus, despite the church owning the structure, and the bells being functionally rung by the congregation or non-congregation, the resulting sound could be appreciated here by both the church and local communities. It follows that 'ownership' of the sounds and thus decision-making power over these sounds might have to 
be given to the community. This, though, has serious ethical implications: should a community be able to dictate to a religious entity to re-commence ringing of silent bells simply for their own enjoyment, especially if it is against the wishes of the church office? At what point do community rights exceed the rights of ownership and control? This becomes even more complex in situations where the soundmarks possess significance at not only a local community level, but also a regional, national, or even international level. An example of the latter, albeit not threatened by silencing, is the sound of 'Big Ben', the 13.6 tonne Bourdon bell mounted in the Elizabeth tower at Westminster.

Clearly, the concept of ownership of heritage and the ideas of religious freedom must be counterbalanced with secular freedom. If religious doctrines of many faiths allow (or require) certain sounds to be broadcast for prayer announcements, religious celebrations, mourning events, or Holy Days, a large combination of faiths in one setting may create conflict, whereby multi-denominational calls might create an irritation or disturbance for each faith group or for any secular subset of the community (Kovačič 2017; Knights 2008). If noise regulations were to exclude sacred sounds from legislation, secular segments of society could be adversely affected, but if the regulations were to include sacred sounds, religious freedom could conceivably become restricted. This is a complex problem in modern society, as all sounds created for a purpose can affect, both positively and negatively, any other person within hearing distance. Future management of these sounds needs to take this into account by raising the societal awareness of religious tolerance alongside a greater awareness of the potential for sound heritage.

Author Contributions: Conceptualization: M.P. and D.H.S.; Methodology: M.P. and D.H.S.; Formal analysis: M.P. and D.H.S.; Investigation: M.P.; Writing-Original Draft: M.P. and D.H.S.; Writing—Review \& Editing: M.P. and D.H.S. Both authors have read and agreed to the published version of the manuscript.

Funding: This research received no external funding.

Conflicts of Interest: The authors declare no conflict of interest.

\section{References}

Acun, Volkan, Semiha Yilmazer, and Pardis Taherzadeh. 2016. Perceived auditory environment in historic spaces of Anatolian Culture: A case study on Haci Bayram mosque. Paper presented at 23rd International Congress on Sound and Vibration, Athens, Greece, July 10-14.

Adamski, Kat. 2011. Residents want 100-year-old St Leonard's Catholic Church bells to stay silent. Daily Telegraph (Sydney), November 16.

Aldoshina, Irina A., and Alexandr Nicanorov. 2000. The Investigation of Acoustical Characteristic of Russian Bells. In Audio Engineering Society Convention 108. New York: Audio Engineering Society.

Aletta, Francesco, Tin Oberman, and Jian Kang. 2018. Associations between positive health-related effects and soundscapes perceptual constructs: A systematic review. International Journal of Environmental Research and Public Health 15: 2392. [CrossRef]

Alvarez-Morales, Lidia, and Francesco Martellotta. 2015. A geometrical acoustic simulation of the effect of occupancy and source position in historical churches. Applied Acoustics 91: 47-58. [CrossRef]

Álvarez-Morales, Lidia, Teófilo Zamarreño, Sara Girón, and Miguel Galindo. 2014. A methodology for the study of the acoustic environment of Catholic cathedrals: Application to the Cathedral of Malaga. Building and Environment 72: 102-15. [CrossRef]

Anglican Church of Australia. 2020. What We Believe. Available online: https://anglican.org.au/about-us/whatwe-believe/ (accessed on 6 August 2020).

Ansay, Samuel, and Paulo Henrique Trombetta Zannin. 2016. Evaluation of the Acoustic Environment in a Protestant Church Based on Measurements of Acoustic Descriptors. Journal of Building Construction and Planning Research 4: 172-89. [CrossRef]

Arnold, John H., and Caroline Goodson. 2012. Resounding community: The history and meaning of medieval church bells. Viator 43: 99-130. [CrossRef] 
Australian Bureau of Statistics. 2017. 2016 Census Data Reveals "No Religion" Is Rising Fast. Available online: https://www.abs.gov.au/AUSSTATS/abs@.nsf/mediareleasesbyReleaseDate/ 7E65A144540551D7CA258148000E2B85 (accessed on 16 August 2018).

Bachmann, Helena. 2018. In Switzerland, church bells alarm those who want silence. USA Today, April 11.

Baldwin, John, Tim Jackson, and Ron Johnston. 2018. Dove's Guide for Church Bell Ringers to the Rings of Bells of the World, 11th ed. New Delhi: Central Council.

BBC. 2017a. Coniston church bells: Pub complainers silence 'noisy' chimes. BBC News, September 19.

BBC. 2017b. Sandwich church bells silenced after neighbour's noise complaint. BBC News, November 22.

Bickman, Leonard, and Debra J. Rog. 2008. The Sage Handbook of Applied Social Research Methods. Southend Oaks: Sage Publications.

Borg, Joe. 2007. Bells' noise pollution. Times of Malta, August 7.

Botteldooren, Dick, Tjeerd Andringa, Itziar Aspuru, Lex Brown, Daniele Dubois, Catherine Guastavino, Catherine Lavandier, Mats Nilsson, and Anna Preis. 2013. Soundscape for European cities and landscape: understanding and exchanging. Paper presented at COST TD0804 Final Conference: Soundscape of European Cities and Landscapes, Merano, Italy, March 22.

Brandt, Sebastian, Wolfgang Maennig, and Felix Richter. 2013. Do Places of Worship Affect Housing Prices? Evidence from Germany. Hamburg: University of Hamburg.

Brink, Mark, Sarah Omlin, Christian Müller, Reto Pieren, and Mathias Basner. 2011. An event-related analysis of awakening reactions due to nocturnal church bell noise. Science of the Total Environment 409: 5210-20. [CrossRef]

Brown, Alexander L. 2011. Advancing the concepts of soundscapes and soundscape planning. Paper presented at Conference of the Australian Acoustical Society, San Diego, CA, USA, October 31-November 4.

Bruce, Neil S., and William J. Davies. 2014. The effects of expectation on the perception of soundscapes. Applied Acoustics 85: 1-11. [CrossRef]

Bunyan, Nigel. 2009. Noisy church bells silenced by complaints. The Telegraph (London), January 23.

Burgess, Clive, and Andrew Wathey. 2000. Mapping the soundscape: church music in English towns, 1450-1550. Early Music History 19: 1-46. [CrossRef]

Burnett, John, ed. 2002. Typikon for Church Ringing. Galperin Mark, trans. Moscow: Editorial Board of the Russian Orthodox Church.

Buszin, Walter E, and Martin Luther. 1946. Luther on music. The Musical Quarterly 32: 80-97. [CrossRef]

Cain, Rebecca, Paul Jennings, and John Poxon. 2013. The development and application of the emotional dimensions of a soundscape. Applied Acoustics 74: 232-39. [CrossRef]

Carney, Josh. 2014. Church bells are noise pollution. Winsford \& Middlewich Guardian, April 3.

Catholic News Agency. 2009. Arizona Catholic church sues to ring its bells. Catholic News Agency, September 6.

Church of England. 1762. The Book of Common Prayer, and Administration of the Sacraments, and Other Rites and Ceremonies of the Church, according to the Use of the Church of England. Oxford: Mark Baskett.

Connexion. 2019. Row over How Loud Bells Toll. The Connexion. Available online: https://www.connexionfrance. com/French-news/residents-of-village-in-southwest-france-face-legal-battle-over-church-bells (accessed on 6 August 2020).

Corbin, Alain. 1998. Village Bells: Sound and Meaning in the 19th-Century French Countryside. Columbia: Columbia University Press.

Crockett, Alasdair, and David Voas. 2006. Generations of decline: Religious change in 20th-century Britain. Journal for the Scientific Study of Religion 45: 567-84. [CrossRef]

Desarnaulds, Victor, António PO Carvalho, and Gilbert Monay. 2002. Church acoustics and the influence of occupancy. Building Acoustics 9: 29-47. [CrossRef]

Diaz, Jordi. 2020. Church bells and ground motions. Journal of Seismology 14: 1-10. [CrossRef]

Dillman, Don A., Jolene D. Smyth, and Leah Melani Christian. 2014. Internet, Phone, Mail, and Mixed-Mode Surveys: The Tailored Design Method. Hoboken: John Wiley \& Sons.

Dumyahn, Sarah, and Bryan Pijanowski. 2011a. Beyond noise mitigation: managing soundscapes as common-pool resources. Landscape Ecology 26: 1311-26. [CrossRef]

Dumyahn, Sarah, and Bryan Pijanowski. 2011b. Soundscape conservation. Landscape Ecology 26: $1327-44$. [CrossRef] 
Dunn, Kevin M, and Awais Piracha. 2015. The multifaith city in an era of post-secularism: The complicated geographies of Christians, non-Christians and non-faithful across Sydney, Australia. In The Changing World Religion Map. Edited by Stanley D. Brunn. Dordrecht: Springer, pp. 1635-54.

Elicio, Luigi, and Francesco Martellotta. 2015. Acoustics as a cultural heritage: The case of Orthodox churches and of the "Russian church" in Bari. Journal of Cultural Heritage 16: 913-18. [CrossRef]

Feld, Steven, and Donald Brenneis. 2004. Doing anthropology in sound. American Ethnologist 31: 461-74. [CrossRef]

Felipe Silva, Luiz, and Rogério Cabral. 2011. Noise Exposure Levels of Priests and Worshippers in Protestant Churches. International Journal of Occupational Safety and Ergonomics 17: 79-86. [CrossRef]

Fowler, Madeline, Amy Roberts, and Lester-Irabinna Rigney. 2019. The sounds of colonization: An examination of bells at Point Pearce Aboriginal Mission Station/Burgiyana, South Australia. In The Sound of Silence: Indigenous Perspectives on the Historical Archaeology of Colonialism. Edited by Tiina Äikäs and Anna-Kaisa Salmi. London: Berghahn Books, pp. 15-39.

García, Laura, Lorena Parra, Blanca Pastor Gomis, Laura Cavallé, Vanesa Pérez Guillén, Herminio Pérez Garrigues, and Jaime Lloret. 2019. Valencia's Cathedral Church Bell Acoustics Impact on the Hearing Abilities of Bell Ringers. International Journal of Environmental Research and Public Health 16: 1564. [CrossRef]

Garrioch, David. 2003. Sounds of the city: the soundscape of early modern European towns. Urban History 30: 5-25. [CrossRef]

Gatty, Alfred. 1848. The Bell: Its Origin, History, and Uses. London: G. Bell.

Ge, Jian, Min Guo, and Miao Yue. 2013. Soundscape of the West Lake Scenic Area with profound cultural background-a case study of Evening Bell Ringing in Jingci Temple, China. Journal of Zhejiang University SCIENCE A 14: 219-29. [CrossRef]

Gerder, Sam. 2020. Church Bell Back Ringing the Hours 80 Years after WW2 Bombing-And Neighbours Submit Noise Complaints. Hackney Gazewtte. Available online: https://www.hackneygazette.co.uk/news/noisecomplaints-after-stoke-newington-church-bell-starts-ringing-hours-for-first-time-in-80-years-1-6509235 (accessed on 6 August 2020).

Goujon, Anne, Vegard Skirbekk, Katrin Fliegenschnee, and P. Strzelecki. 2007. New times, old beliefs: Investigating the future of religions in Austria and Switzerland. Joint Eurostat/UNECE Work Session on Demographic Projections, Bucharest 10-12 Oct 2007 10: 347-60.

Hargraves, Fionn. 2018. They shall not be silenced! Church bells will receive protection from noise complaints under new planning rules. Daily Mail, January 20.

Haroldson, Brett J. 2015. Saved by the Bells: A Look at Campanological Rights of US Churches. Rutgers Journal of Law \& Religion 17: 83-120.

Hernandez, Richard L. 2004. Sacred sound and sacred substance: Church bells and the auditory culture of Russian villages during the Bolshevik Velikii Perelom. The American Historical Review 109: 1475-504. [CrossRef]

His Master's Voice. 1946. Side A: Bells of (a) Westminster Abbey, (b) York Minster, (c) Coventry Catahdral. Side B: (a) Bath Abbey; (b) St. Mary's Puddleton. Rung on Victory day, May 8th, 1945 (Commentator: Frank Phillips) OEA 10480. B.9417-78 r.p.m. London: His Master's Voice, Gramophone Co. Ltd.

Hong, Joo Young, Pyoung Jik Lee, and Jin Yong Jeon. 2010. Evaluation of urban soundscape using soundwalking. Paper presented at 20th International Congress on Acoustics, Sydney, Australia, August 23-27.

Hooper, John. 2008. Italy: Priest fined $€ 60,000$ as loud church bells take their toll. The Guardian, September 3.

Jin Yong, Jeon, Hwang In Hwan, and Hong Joo Young. 2014. Soundscape evaluation in a Catholic cathedral and Buddhist temple precincts through social surveys and soundwalks. Journal of the Acoustical Society of America 135: 1863-74. [CrossRef]

Jones, James W. 2019. Living Religion: Embodiment, Theology, and the Possibility of a Spiritual Sense. Oxford: Oxford University Press.

Kang, Jian, Francesco Aletta, Truls T. Gjestland, Lex A. Brown, Dick Botteldooren, Brigitte Schulte-Fortkamp, Peter Lercher, Irene van Kamp, Klaus Genuit, André Fiebig, and et al. 2016. Ten questions on the soundscapes of the built environment. Building E Environment 108: 284-94. [CrossRef]

Kato, Kumi. 2009. Soundscape, cultural landscape and connectivity. Sites A Journal of Social Anthropology and Cultural Studies 6: 80-91. [CrossRef]

Kaysen, Ronda. 2015. Ask Real Estate. When the Noisy Neighbor is a Church. New York Times, November 21.

Kelly, Olivia. 2013. Noise complaint silences church bells after 130 years. Irish Times, September 21. 
Killoran, Matthew, and Chris McMahon. 2014. Unholy row as neighbours complain that noisy churches are... taking the peace. Courier Mail, February 16.

Kiser, Brenda H., and David Lubman. 2008. The soundscape of church bells-sound community or culture clash. Journal of the Acoustical Society of America 123: 3807. [CrossRef]

Kitapci, Kivanc, and Laurent Galbrun. 2015. Subjective speech intelligibility and soundscape perception of English, Polish, Arabic and Mandarin. In INTER-NOISE and NOISE-CON Congress and Conference Proceedings. Reston: Institute of Noise Control Engineering.

Knights, Samantha. 2008. Sacred space and the city: Religious buildings and noise pollution. Harvard International Law Journal Online 49: 50-55.

Kovačič, Mojca. 2006. The bell and its symbolic role in Slovenia. Tautosakos darbai 32: 105-16.

Kovačič, Mojca. 2009. The Use of the Church Bell: From Signaling Device to Musical (Percussion) Instrument. In Studia Instrumentorum Musicae Popularis. Edited by Gisa Jähnichen. Münster: Monsenstein und Vannerdar, pp. 109-22.

Коvačič, Мојса. 2017. Official Regulations and Perceptual Aspects of Bell Ringing. МУЗИКОЛОГИЈА/Musicology 22: 59-73.

Kumar, Anish, T. Jayakumar, C. Babu Rao, Govind K. Sharma, K. V. Rajkumar, Baldev Raj, and P. Arundhati. 2008. Nondestructive characterization of musical pillars of Mahamandapam of Vitthala Temple at Hampi, India. The Journal of the Acoustical Society of America 124: 911-17. [CrossRef]

Lam, Kin-Che, A. L. Brown, Lawal Marafa, and Kwai-Cheong Chau. 2010. Human preference for countryside soundscapes. Acta Acustica united with Acustica 96: 463-71. [CrossRef]

Lloyd, William H. 1934. Noise as a nuisance. University of Pennsylvania Law Review 82: 567-82. [CrossRef]

Local. 2018. Sleepless in Switzerland: could quieter church bells be the answer? The Local CH, April 10.

Lubken, Deborah. 2016. How Church Bells Fell Silent: The Decline of Tower Bell Practices in Post-Revolutionary America. Ph.D. Dissertation, Department of Communication, University of Pennsylvania, Philadelphia, PA, USA.

McCrindle. 2019. Faith \& Giving in Australia. Exploring Generosity and Giving Habits of Australian Churchgoers. Baulkham Hills: McCrindle.

Mellor, Philip A, and Chris Shilling. 2010. The Religious Habitus: Embodiment, Religion, and Sociological Theory (Chapter 9). In The New Blackwell Companion to the Sociology of Religion. Edited by Bryan S. Turner. Chichester: John Wiley \& Sons, pp. 201-20.

Minchin, Rod. 2010. Time called on Wrington's 'noisy' church clock. The Independent, April 25.

Minoura, Kazuya. 2013. Life with weaving noise in Fujiyoshida: A soundscape as a commons. Paper presented at 14th Global Conference of the International Association for the Study of the Commons, Mount Fuji, Japan, June 3-7.

Morgan, David. 2009. The material culture of lived religion: Visuality and embodiment. In Mind and Matter: Selected Papers of Nordic Conference. London: PhilPapers.

Murdoch, Jude. 2010. Sound Off? Legal Checks on Religious Noise in New Zealand. Bachelor's Dissertation, University of Otago, Dunedin, New Zealand.

Oancea, C., Constantin Gheorghies, and Simona Condurache-Bota. 2010. Comparative Analysis of Bell Sounds from Several Romanian Orthodox Monasteries and Churches. Journal of Science and Arts 10: 199-204.

Omlin, Sarah, and Mark Brink. 2013. Awakening effects of church bell noise: Geographical extrapolation of the results of a polysomnographic field study. Noise and Health 15: 332-41. [CrossRef]

Orfali, Wasim A. 2007. Sound parameters in mosques. In Proceedings of Meetings on Acoustics 153ASA. Melville: Acoustical Society of America.

Orfali, Wasim A, and Wolfgang Ahnert. 2006. Measurements and verification of two mosques in Saudi Arabia. The Journal of the Acoustical Society of America 119: 3208. [CrossRef]

Park, Andrea, and Randy Mac. 2015. NBC News. I Don't Want to Hear It: Woman Fights to Stop Nearby Church Bells, No. NBC Los Angeles. Available online: https:/www.nbclosangeles.com/news/woman-fights-to-stopnearby-church-bells-2/114697/ (accessed on 5 August 2020).

Parker, Murray. 2018. The Heritage of Sound in the Built Environment: An Exploration. Bachelor's dissertation, School of Environmental Sciences, Charles Sturt University, Bathurst, Australia.

Parker, Murray, and Dirk H.R. Spennemann. n.d.a. Bells and bell-ringing practices in New South Wales. Material Religion, under review. 
Parker, Murray, and Dirk H.R. Spennemann. n.d.b. Classifying sound in the heritage environment. Applied Acoustics, under review.

Parker, Murray, and Dirk H.R. Spennemann. n.d.c. Conceptualising sound making and sound loss in the urban heritage environment. International Journal of Urban Sustainable Development, under review.

Pew. 2020. Religious Landscape Study. Attendance at Religious Services. Available online: https://www. pewforum.org/religious-landscape-study/attendance-at-religious-services/ (accessed on 5 August 2020).

Pimentel, Sarah-Leah. 2019. For whom the bell tolls: Prayer or noise? Spotlight Africa, May 22.

Plahuta, Marko. 2013. Noise pollution caused by church towers in Ljubljana. Virostatiq. Visualization, Language and Culture (Blog). Available online: http://virostatiq.com/sound-pollution-caused-by-church-towers-inljubljana/ (accessed on 5 August 2020).

Prasad, Marehalli. 2015. Conch-shells, bells, and gongs in Hindu temples. The Journal of the Acoustical Society of America 137: 2427-27. [CrossRef]

Rathke, Lisa. 2015. Joyful noise or unholy din? Vermont Church 'bells' mean discord. Portland Press Herald, May 4. Raven, John James. 1890. The Church Bells of Suffolk: A Chronicle in Nine Chapters, with a Complete List of the Inscriptions on the Bells, and Historical Notes. Norwich: Jarrold and Sons.

Rossing, Thomas D. 2000. Science of Percussion Instruments. Singapore: World Scientific.

Salom, Iva M., Miomir M. Mijić, Jelena D. Ćertić, Dragana S. Šumarac Pavlović, and Boris D. Despot. 2014. Subjective evaluation and an objective measure of a church bell sound quality. Applied Acoustics 85: 97-105. [CrossRef]

Sarantakos, Sotirios. 2008. Social Research. London: Red Globe Press.

Scammell, Rosie. 2015. Italian church fined $€ 1,300$ for noisy bells. The Local IT, February 23.

Schafer, R. Murray. 1994. The Soundscape: Our Sonic Environment and the Tuning of the World. Vermont: Destiny Books.

Schwartz, Hillel. 1995. Noise and Silence: The Soundscape and Spirituality. Realizing the Ideal: The Responsility of the World's Religions Section IV, Religion and the Ideal Environment 20-27 August 1995, Seoul, Korea. Available online: https://www.nonoise.org/library/noisesil/noisesil.htm (accessed on 5 August 2020).

Skirbekk, Vegard, Eric Kaufmann, and Anne Goujon. 2010. Secularism, fundamentalism, or Catholicism? The religious composition of the United States to 2043. Journal for the Scientific Study of Religion 49: 293-310. [CrossRef]

Soeta, Yoshiharu, Ryota Shimokura, Yong Hee Kim, Tomohiro Ohsawa, and Ken Ito. 2013. Measurement of acoustic characteristics of Japanese Buddhist temples in relation to sound source location and direction. The Journal of the Acoustical Society of America 133: 2699-710. [CrossRef]

Suárez, Rafael, Alicia Alonso, and Juan J. Sendra. 2015. Intangible cultural heritage: The sound of the Romanesque cathedral of Santiago de Compostela. Journal of Cultural Heritage 16: 239-43. [CrossRef]

Suárez, Rafael, Alicia Alonso, and Juan J. Sendra. 2016. Archaeoacoustics of intangible cultural heritage: The sound of the Maior Ecclesia of Cluny. Journal of Cultural Heritage 19: 567-72. [CrossRef]

Syamsiyah, Nur Rahmawati, Atyanto Dharoko, and Sentagi Sosetya Utami. 2018. Sound preservation at the Grand Mosque of Yogyakarta in Indonesia: The acoustic performance of the traditional architecture. In AIP Conference Proceedings. Melville: AIP Publishing LLC.

The Uniting Church in Australia. 2020. About the Uniting Church in Australia. Available online: https: //assembly.uca.org.au/about/uca (accessed on 6 August 2020).

Trikootam, Sai Charan, and Maarten Hornikx. 2019. The wind effect on sound propagation over urban areas: Experimental approach with an uncontrolled sound source. Building and Environment 149: 561-70. [CrossRef]

Union of Catholic Asians. 2012. Poland. Court Finds Priest Guilty for Ringing Church Bells. Union of Catholic Asian News. Available online: https://www.ucanews.com/news/court-finds-priest-guilty-forringing-church-bells/52893 (accessed on 5 August 2020).

Van der Merwe, C. G., and Matthew Blumberg. 1998. For Whom the Bell Tolls-A Solution in Neighbour Law. Stellenbosch Law Review 9: 351-57.

Vickery, Kit. 2020. Church bells and loud footsteps among hundreds of noise complaints across Bolton. Bolton News, April 8.

Watkin, Thomas Glyn. 1996. A Happy Noise to Hear? Church Bells and the Law of nuisance. Ecclesiastical Law Journal 4: 545-55. [CrossRef]

Weiner, Isaac. 2014. Religion out Loud. Religious Sound, Public Space, and American Pluralism. New York: New York University Press. 
Westermeyer, Paul. 2009. A Hymnal's Theological Significance. Dialog 48: 313-19. [CrossRef]

Wood, Sam. 2010. Too loud too early for Manayunk church bell, neighbor complains. Philadelphia Enquirer, September 9.

Yilmazer, Semiha, and Volkan Acun. 2018. A grounded theory approach to assess indoor soundscape in historic religious spaces of Anatolian culture: A case study on Hacı Bayram Mosque. Building Acoustics 25: 137-50. [CrossRef]

Zhang, Dongxu, Mei Zhang, Daping Liu, and Jian Kang. 2016. Soundscape evaluation in Han Chinese Buddhist temples. Applied Acoustics 111: 188-97. [CrossRef] article distributed under the terms and conditions of the Creative Commons Attribution (CC BY) license (http://creativecommons.org/licenses/by/4.0/). 